\title{
Aspek Pendidikan Karakter dalam Sinetron "Dunia Terbalik" dan Sumbangannya Sebagai Materi Pembelajaran Sastra Indonesia di Sekolah
}

\author{
Filantropi Nola Rizki ${ }^{1}$, Lulus Irawati ${ }^{2}$ \\ 1,2) Universitas PGRI Madiun, Jl. Setiabudi No. 85, Madiun, Indonesia \\ e-mail: 1) nola_filantropi@yahoo.com; ${ }^{2)}$ lulusirawati@unipma.ac.id
}

\begin{abstract}
Abstrak
Tujuan dari penelitian ini adalah: (1) untuk mengidentifikasi aspek pendidikan karakter dalam sinetron Dunia Terbalik, (2) sumbangannya sebagai materi pembelajaran sastra Indonesia di sekolah. Metode penelitian yang digunakan adalah deskriptif kualitatif dengan analisis isi. Sumber data yang digunakan berupa sinetron Dunia Terbalik, dengan dokumentasi sebagai teknik pengumpulan data. Teknik keabsahan data yang digunakan adalah teknik trianggulasi. teknik analisis data dalam penelitian ini adalah analisis isi atau content analysis. Hasil analisis menunjukkan bahwa: (1) aspek pendidikan karakter dari sinetron Dunia Terbalik meliputi: religius, kejujuran, kesabaran, kerja keras, cinta tanah air, kekeluargaan, cinta damai, peduli sosial, dan tanggung jawab. (2) hasil aspek pendidikan karakter disumbangkan kepadaguru sebagai materi pembelajaran sasta Indonesia di sekolah dan dapat diterapkan dari tingkat jenjang Sekolah Menengah Pertama (SMP), Sekolah Menengah Atas (SMA). Penelitian ini dapat digunakan untuk pengembangan materi pembelajaran sastra Indonesia berdasarkan aspek pendidikan karakter.
\end{abstract}

Kata kunci: Pendidikan Karakter; Materi Pembelajaran Sastra Indonesia

\section{Character Education Aspects in Electronic Cinema Dunia Terbalik and the Contribution for the Learning Materials of Indonesian Literature Subject}

\begin{abstract}
The objectives of the research are: (1) to identify the character aspects in cinema Dunia Terbalik, (2) to arrange the character aspects as Indonesian Literature learning materials. The method of the research was descriptive qualitative with content analysis. The data were document in the form of manuscript of cinema Dunia Terbalik, with documentation as data collecting technique. Triangulation was used as the data validating technique. Data analysis was carried out by using interactive model. The results of the analysis show that: (1) character aspects of Dunia Terbalik include religiosity, honesty, patience, hard work, patriotism, kinship, peace, social awareness and responsibility. (2) The character aspects are designed in the teachers'lesson plans for the junior and senior high school's classes. This research can be upgraded to the development of learning material based on character aspects.
\end{abstract}

Keywords: Character Education; Learning Materials of Indonesian Literature

\section{Pendahuluan}

Pembentukan karakter merupakan bagian yang penting dalam proses pendidikan suatu bangsa. Pembentukan karakter perlu ditanamkan pada anak sejak dini, dengan tujuan agar pada saat dewasa anak memiliki nilai karakter yang positif. Pada umumnya pembentukan karakter dapat ditanamkan melalui oarng tua, lingkungan, 
masyarakat, dan sekolah. Menanamkan nilai karakter pendidikan pada anak difungsikan untuk mempersiapkan generasi muda yang berkualitas di era globalisasi dan dapat bersaing dengan bebas.

Melalui pendidikan karakter pada anak-anak, diharapkan mampu menumbuhkan kembali karakter yang sesungguhnya pada anak. Tujuan pembelajaran sastra disekolah bukan hanya membuat siswa pintar dalam berbahasa Indonesia, namun membentuk karakter dan watak siswa adalah salah satu tanggung jawab dalam tujuan pembelajaran sastra Indonesia dan merupakan tanggung jawab setiap guru bukan hanya guru mata pelajaran bahasa Indonesia. Menurut Wibowo (2013:15), pendidikan karakter adalah pendidikan yang menanamkan dan mengembangkan karakter-karakter luhur kepada anak didik, sehingga mereka memiliki karakter luhur itu, menerapkan dan mempraktikkan dalam kehidupannya, baik itu dalam keluarga, maupun sebagai anggota masyarakat dan warga negara. Jadi menanamkan pendidikan karakter itu diwajibkan karena untuk kelangsungan hidup dimasa yang akan datang.

Pendidikan karakter dilakukan untuk menanamkan nilai karakter pada peserta didik, sejalan dengan pendapat tersebut menurut Mulyasa (2014:7), pendidikan karakter merupakan suatu sistem penanaman nilai-nilai berkarakter kepada peserta didik yang meliputi komponen kesadaran, pemahaman, kepedulian dan komitmen tinggi untuk melaksanakan nilai-nilai tersebut, baik terhadap Allah Tuhan Yang Maha Esa, diri sendiri, sesama, lingkungan, maupun masyarakat dan bangsa secara keseluruhan, sehingga menjadi manusia sempurna sesuai kodratnya.

Televisi atau yang sering disebut TV merupakan salah satu media massa yang sangat berpengaruh terhadap masyarakat. Menurut Karlinah (2009:6), televisi merupakan media dari jaringan komunikasi yang memilki ciri-ciri sama seperti media massa, bersifat satu arah, komunikatornya melembaga, pesannya bersifat umum, sasarannya bersifat keserempakan dan komunikatornya bersifat heterogen. Dengan demikian, jelas bahwa televisi memegang peranan penting dalam melakukan komunikasi untuk menyampaikan suatu pesan atau informasi kepada masyarakat umum yang berada di tempat yang berbeda.

Media televisi (TV) juga bisa berfungsi sebagai alat penyalur pesan dari pemberi pesan (pendidik, penulis buku, produser dan sebagainya) ke penerima pesan (siswa, pelajar, peserta didik, dan masyarakat). Televisi (TV) dapat mewakili pendidik untuk halhal tertentu dengan lebih teliti, jelas, dan menarik. Video, VCD dan TV juga memberikan kemudahan yang luar biasa untuk memperlancar proses pendidikan (Rokib, 2009:70). Pendapat tersebut jelas, bahwa dengan menggunakan media yang semakin canggih, akan mempermudah untuk mengenalkan nilai-nilai karakter pendidikan yang dapat diberikan pendidik, guru, orang tua, maupun lingkungan masyarakat.

Ditengah banyaknya tayangan di televisi (TV), ada salah satu tayangan sinetron yang dapat menarik masyarakat dalam menonton sinetron tersebut yaitu sinetron dramakomedi-Islami yang ditayangkan di RCTI sejak tanggal 5 Januari2017. Sinetron ini diproduksi oleh MNC Pictures dengan judul sinetron Dunia Terbalik. Sinetron ini memberikan warna yang baru untuk dunia perteleviasian terutama dikalangan masyarakat luas.

Dalam hal ini, peneliti ingin menggali aspek nilai-nilai pendidikan karakter yang ada dalam cerita yang terdapat pada sinetron Dunia Terbalik. Sinetron dengan judul Dunia Terbalik adalah sebuah sinetron inspiratif yang penuh dengan nilai karakter 
pendidikan. Cerita dalam sinetron ini mengisahkan tentang komedi yang mengangkat cerita tentang para suami yang ditinggalkan istrinya untuk bekerja di luar negeri. Dimulai dari kisah Akum, Aceng, Idoy, dan Dadang sebagai suami. Mereka harus mendidik anak serta mengurus urusan rumah tangga yang biasanya menjadi urusan para wanita. Sementara istrinya harus menafkahi keluarga dan bekerja diluar negeri. Dalam cerita ini juga menggambarkan kehidupan bermasyarakat dan memberikan warna yang baru untuk saling menghargai dan tolong menolong satu sama lain.

\section{Metode Penelitian}

Metode penelitian yang digunakan dalam penelitian ini adalah deskriptif kualitatif. Sumber data yang digunakan adalah sinetron Dunia Terbalik. Teknik pengumpulan data yang digunakan adalah metode dokumentasi, metode dokumentasi pada penelitian ini menggunakan: teknik simak, teknik mencatat, dan teknik melihat dengan adeganadegan yang menggambarkan nilai-nilai pendidikan karakter yang terdapat dalam sinetron Dunia Terbalik. Prosedur penelitian yang digunakan dalam penelitian ini meliputi: tahap persiapan, tahap pengumpulan data, tahap analisis data, dan tahap akhir. Sedangkan teknik keabsahan data menggunakan teknik trianggulasi dan teknik analisis data dalam penelitian ini adalah analisis isi atau content analysis.

\section{Hasil dan Pembahasan}

Nilai-nilai pendidikan karakter yang diperoleh dalam sinetron Dunia Terbalik diharapkan para penonton atau para siswa akan mendapatkan nilai-nilai positif yang memberikan pengaruh positif bagi penonton yang menontonnya. Artinya pendidikan karakter yang diharapkan dalam sinetron Dunia Terbalik ini akan mengarah pada sisi afektif dan berlanjut pada sisi psikomotorik penontonnya. Nilai-nilai tersebut dikembangkan agar penonton dapat menghayati dan mengamalkan nilai-nilai pendidikan karakter pribadinya. Nilai-nilai pendidikan karakter yang telah didapatkan dalam sinetron Dunia Terbalik yaitu nilai religius, kejujuran, kesabaran, kerja keras, cinta tanah air, kekeluargaan, cinta damai, peduli sosial, dan tanggung jawab.

\section{Nilai-nilai Pendidikan Karaker dalam Sinetron "Dunia Terbalik" dan Sumbangan Hasil Penelitian sebagai Materi Pembelajaran Sastra Indonesia Di Sekolah \\ a. Nilai Religius}

Nilai religius merupakan hubungan antara manusia kepada Tuhan-Nya, hubungan sesama manusia, dan hubungan antara manusia dengan alam lingkungannya.

"Kalian tau, apa saat-saat indah dalam hidup ini? Bukan ketika kalian sukses, bukan juga ketika kalian mendapatkan apa yang kalian inginkan. Saat-saat yang paling indah dalam hidup ini adalah ketika kalian tidak memiliki apa-apa, ketika ujian datang dari segala penjuru, ketika orang-orang meninggalkan kalian dan kalian menggerakkan kaki dan tangan kalian berusaha dan kalian yakin Allah akan membantu. Itulah ikhlas dan sabar yang sesungguhnya. Ko paham?.."

"Isyaallah paham pak ustad.."

"Kalau diam mah saya tau, dia mangut-mangut tidak paham.."

"Mul, udah masuk waktu magrib. Adzan.."

"lya Pak Ustad.." 


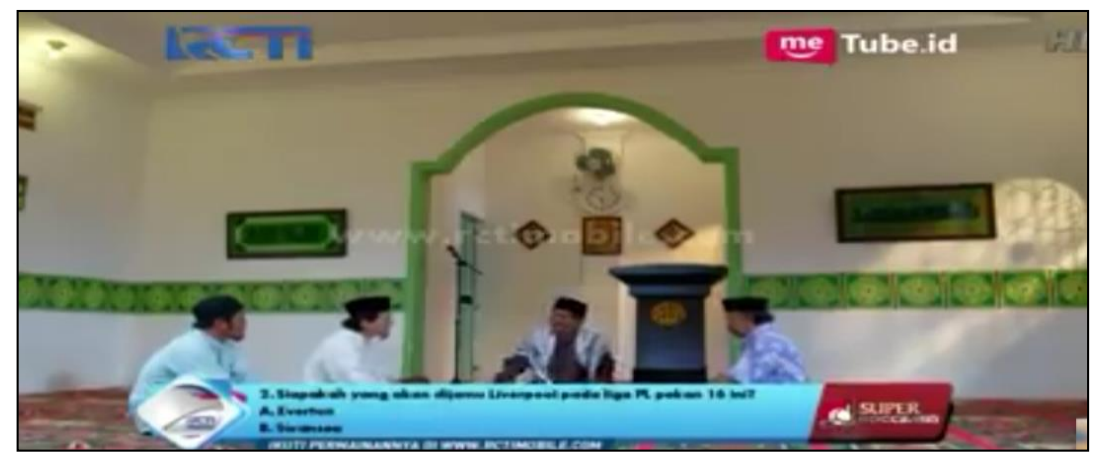

Gambar 1. Tokoh Pak Ustad Kemed dan Warga Ciraos dalam Sinetron "Dunia Terbalik" Episode 399

Warga Ciraos dalam sinetron Dunia Terbalik ini memiliki sosok panutan dalam kehidupan mereka yaitu Pak Ustad Kemed. Pak Ustad Kemed merupakan sosok orangtua yang cukup disegani dan banyak dari warga Ciraos yang meminta nasehat atau arahan nika mereka dilanda masalah. Pak Ustad kemed ini juga sosok orang yang selalu rajin ke mesjid untuk memberikan ceramah atau wejangan kepada warga yang datang. Memberikan arahan mana yang baik dan mana yang buruk. Dan juga selalu mengingatkan warganya jika waktu Azan dan sholat akan datang.

Hasil penelitian yang terdapat dalam nilai religius dapat disumbangkan pada tingkat Sekolah Menengah Pertama (SMP) dan dapat dijadikan sebagai media pembelajaran sastra Indonesia di kelas VIII semester 2 yang terdapat materi pokok tentang teks drama dengan Kompetensi Inti dan Kompetensi Dasar (KD) sebagai berikut:

Kompetensi Inti : 1. Menghargai dan menghayati ajaran agama yang dianutnya

Kompetensi Dasar : 1.1 Menghargai dan mensyukuri keberadaan Bahasa Indonesia sebagai anugerah Tuhan Yang Maha Esa untuk mempersatukan bangsa Indonesia di tengah keberagaman bahasa dan budaya 1.2 Menghargai dan mensyukuri keberadaan bahasa Indonesia sebagai anugrah Tuhan yang Maha Esa sebagai sarana memahami informasi lisan dan tulis.

1.3 Menghargai dan mensyukuri keberadaan bahasa Indonesia sebagai anugrah Tuhan yang Maha Esa sebagai sarana menyajikan informasi lisan dan tulis

Hasil penelitian ini juga dapat di terapkan pada Sekolah Menengah Atas (SMA) dengan Kompetensi Inti dan Kompetensi Dasar (KD) SMA Kelas XI Semester 2 dengan materi drama:

Kompetensi Inti : 1 . Menghayati dan mengamalkan ajaran agama yang dianutnya Kompetensi Dasar : 1.1 Mensyukuri anugerah Tuhan akan keberadaan Bahasa Indonesia dan menggunakannnya sesuai dengan kaidah dan konteks untuk mempersatukan bangsa

1.2 Mensyukuri anugerah Tuhan akan keberadaan bahasa Indonesia dan menggunakannya sebagai sarana komunikasi dalam memahami, menerapkan, dan menganalisis informasi lisan dan tulis melalui cerita pendek, pantun, cerita ulang, eksplanasi kompleks, dan ulasan/reviu film/drama. 
1.3 Mensyukuri anugerah Tuhan akan keberadaan bahasa Indonesia dan menggunakannya sebagai sarana komunikasi dalam mengolah, menalar, dan menyajikan informasi lisan dan tulis melalui cerita pendek, pantun, cerita ulang, eksplanasi kompleks, dan ulasan/reviu film/drama

\section{b. Nilai Kejujuran}

Nilai kejujuran merupakan upaya untuk jujur tanpa menutupi sesuatu hal ataupun perbutan yang dilakukan.

"Kalian setiap hari ya makan burger?"

"Gak juga Per, jarang-jarang kok..."

"Kalau kamu Deb?"

"Kalau dulu sering, kalau sekarang jarang. Palingan kalau jalanjalan ke Bogor sama Papa, soalnya takut gendut”...

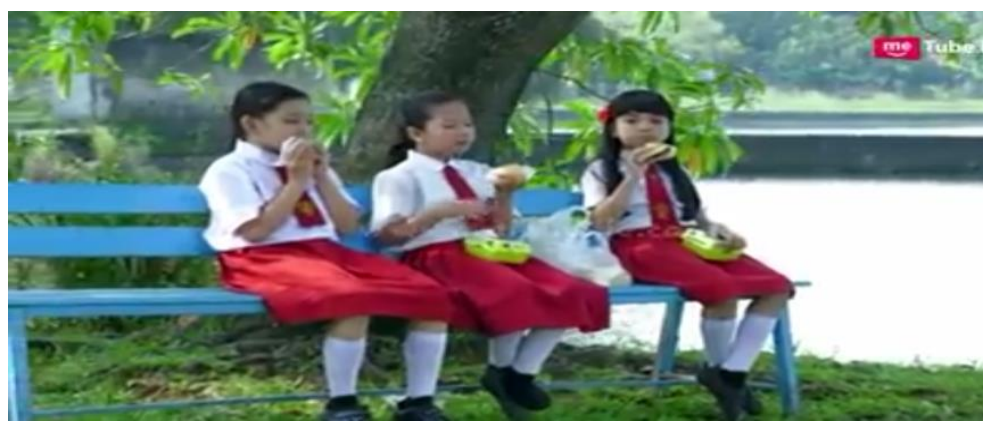

Gambar 2. Tiga Tokoh Anak dalam Sinetron Dunia Terbalik Episode 402

Nilai kejujuran dalam sinetron Dunia Terbalik tersebut ditunjukkan oleh ketiga tokoh anak dalam sinetron ini, disaat salah satu diantara mereka menanyakan tentang burger. Mereka tetap menjawab dengan jujur dan tidak menunjukkan sifat sombong atau bohong. Mereka masih kelihatan polos, tidak menampakkan kalau mereka sedang berbohong atau menutupi sesuatu dari pertanyaan yang diberikan.

\section{c. Nilai Kesabaran}

Sabar merupakan suatu sikap dalam menahan emosi atau suatu keinginan, serta bertahan dalam situasi sulit dengan tidak mengeluh.

"Assalamualaikum Mak (mengetok pintu).."

"Waalaikumsalam (membuka pintu).."

"Saya duduk ya Mak ....."

"Silahkan (sambil menunjuk kursi yang berada didekat Mak Suha)...."

"Eh, gak. Maksud saya, saya duduk disini Mak (menunjuk kursi lainnya), bukan duduk disitu ..."

"Emang kamu mau lama ngobrolnya?.."

"Ya gak tau Mak (dengan wajah bingung), pas saya datang Aceng lagi makan (jawabannya tidak nyambung).."

"Maksud Mak, ngobrol disininya (dengan penuh kesabaran)..."

"Nah, kalau itu saya gak tau Mak.." 


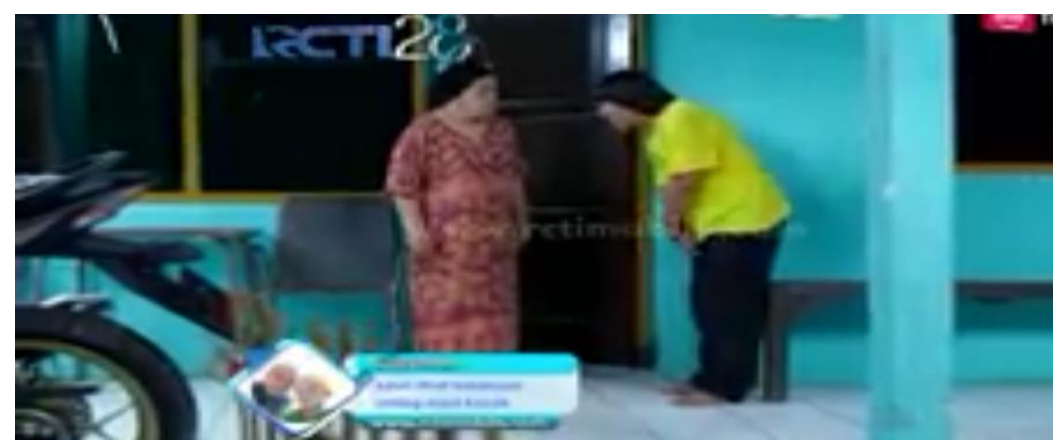

Gambar 3. Tokoh Idoy dan Mak Suha dalam Sinetron Dunia Terbalik Episode 401

Nilai kesabaran dapat dilihat pada adegan tokoh Idoy mendatangi rumah Mak Suha. Tokoh Idoy memiliki peran yang sangat menguji kesabaran bagi orang yang akan berbicara atau ngobrol bersama dia. Idoy adalah seorang laki-laki (bapak) yang cukup lambat dalam menangkap pembicaraan. Butuh kesabaran ekstra dalam menjelaskan segala hal.

\section{d. Nilai Kerja Keras}

Nilai kerja keras merupakan prilaku yang menunjukkan upaya yang sesungguhnya dalam mengatasi berbagai hambatan belajar dan tugas, serta menyelesaikan tugas dengan sebaik-baiknya.

"Cilok... Cilok... dicilokin yeee"...

"Cilok Encuy mah Cuma 500 san"..

"Cilok.. Cilok.. Dicilokkan yeee (bernyanyi)"...

"Hai bos Bray"..

"Assalamualaikum Cuy"..

"Waalaikumsalam bos Bray, cilok bos Bray?"..

"Bikinin 5000 aja Cuy"..

"Kalau buat bos Bray sambalnya yang banyak yaa (senyum), sebentar yaaa"...

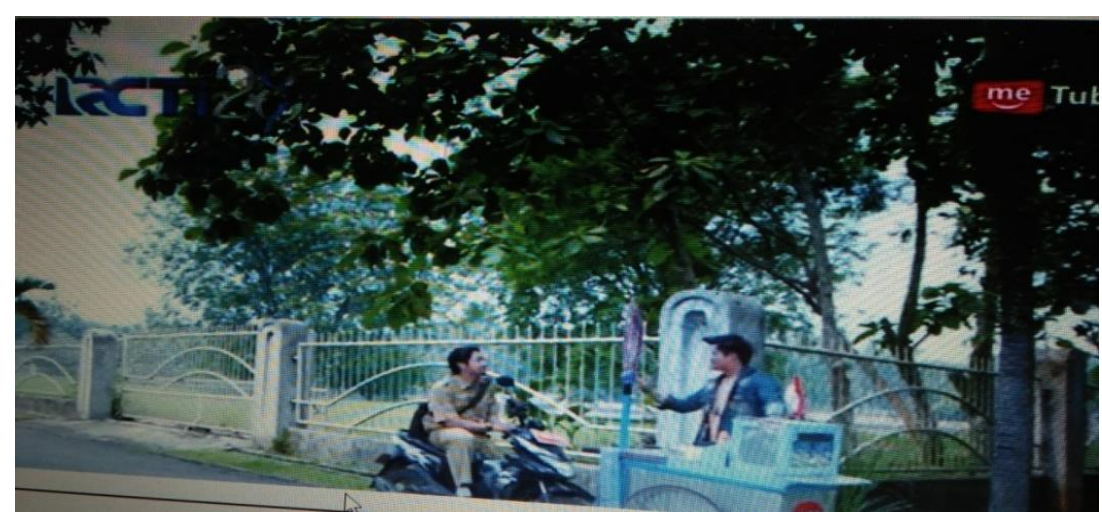

Gambar 4. Tokoh Encuy dan Bos Sobray dalam Sinetron Dunia Terbalik Episode 401 
Nilai kerja keras juga tampak pada adegan tokoh Encuy, seorang pedangan cilok keliling. Tokoh Encuy menggambarkan sosok laki-laki (suami) yang pekerja keras, untuk mencari uang dengan berjualan Cilok. Tanpa ada rasa malu dan patah semangat, tokoh Encuy tetap terus berkeliling jualan cilok. Tokoh Encuy pada adegan ini, dapat dijadikan gambaran bahwa kita tetap harus bekerja keras dalam hal apapun, ini merupakan gambaran nilai kerja keras yang dapat dijadikan contoh untuk siapapun yang menonton dan melihat sinetron Dunia Terbalik.

\section{e. Nilai Cinta Tanah Air}

Merupakan cara berfikir, bertindak, dan perbuatan yang menunjukkan kesetiaan, kepedulian dan penghargaan, yang tinggi terhadap bahasa, lingkungan fisik, sosial, budaya, ekonomi, dan politik bangsa .

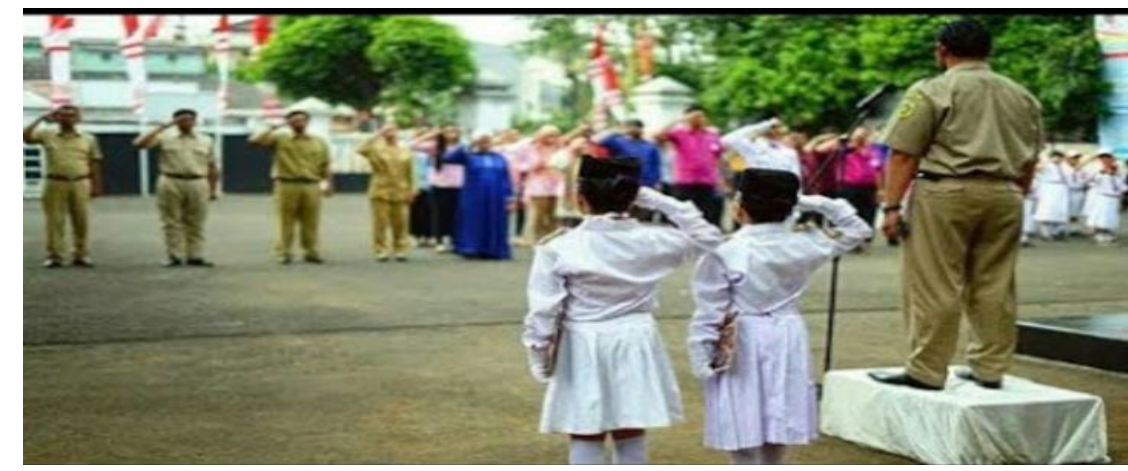

Gambar 5. Warga Ciraos dalam Sinetron Dunia Terbalik Episode 400

Nilai cinta tanah air ini dapat digambarakan pada perayaan acara 17 Agustus yang dilakukan oleh para warga Ciraos. Perangkat desa, orangtua, warga, hingga anakanak desa Ciraos mempringati hari kemerdekaan Indonesia dengan mengikuti upacara hari 17 Agustus tersebut. Upacara yang hikmat dengan memaknai hari kemerdekaan dengan penuh perjuangan para pahlawan membela dan mempertahankan bangsa Indonesia. Dengan terus mengajak anak-anak untuk cinta tanah air, maka akan mengajarkan mereka dan menanamkan arti kemerdekaan untuk mereka.

\section{f. Nilai Kekeluargaan}

Nilai kekeluargaan, maksudnya adalah rasa senang berbicara, bersama-sama, bergaul, dan bekerja sama dengan membatu orang lain.

(Dede menangis didalam rumah dan Sobry mendatangi istrinya)

"Dede cantik kenapa?"

"Aa' (sedih dan menangis)"

"Ada apa? Kenapa? Cerita sama Aa' Sobry"

"Dede pengen punya anak Aa' .."

"Iya Dede cantik, Aa' juga. Kalau Allah mengizinkan, kita pasti punya anak. Yaaa (menenangkan)"

"Gimana kalau Dede gak bisa lagi punya anak Aa'?.."

"Jangan ngomong kayak gitu, jangan ngomong gitu. Gak bagus, gak baik. Insyaalah kita bisa punya anak..." 
(memeluk dan memberi ketenangan untuk selalu tetap percaya akan kuasa Allah SWT)...

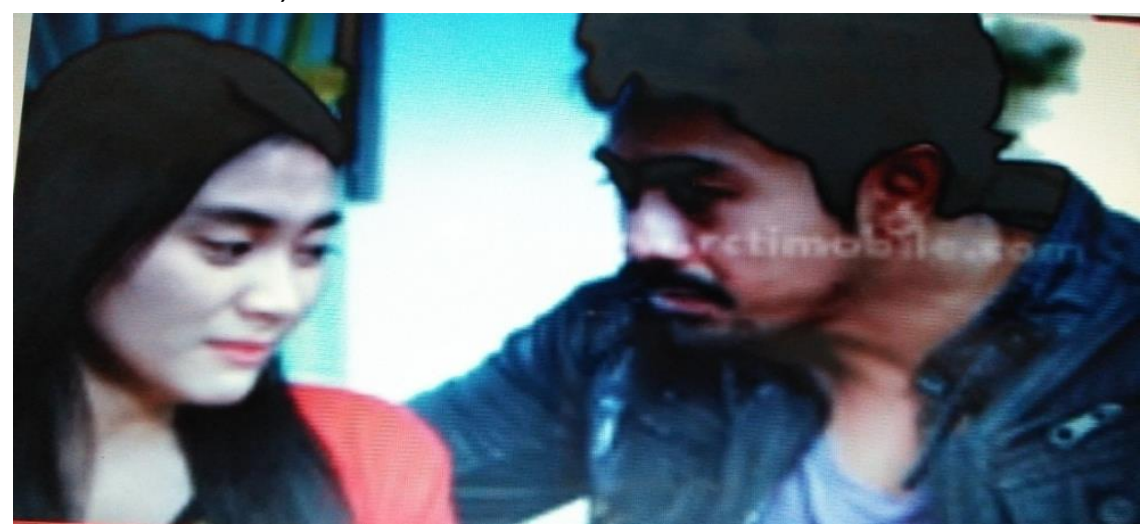

Gambar 6. Tokoh Dede dan Sobry dalam Sinetron Dunia Terbalik Episode 339

Nilai kekeluargaan disini digambarkan oleh tokoh-tokoh dalam sinetron Dunia terbalik yaitu Dede dan Sobry. Tokoh Dede dan Sobry merupakan suami istri dan membangun sebuah keluarga yang harmonis, walaupun dalam sebuah keluarga tidak akan luput dari sebuah masalah. Masalah yang sedang dihadapi mereka adalah mereka yang belum memiliki keturunan. Dede sedang meratapi kesedihan karena ia belum diberi keturunan dan membicarakan hal tersebut kepada suaminya yaitu Sobry. Mereka samasama berbicara dan mencoba mencari jalan keluar atas masalah yang dihadapi, tokoh sobry memberikan ketenangan atas kegelisahan istrinya dengan dialog "lya dede cantik, aa' juga. Kalau Allah mengizinkan, kita pasti punya anak". Jelas dari dialog tersebut, tokoh Sobry sebagai suami tetap menerima istrinya apapun yang terjadi dan mereka tetap bersama-sama dalam membangun sebuah keluarga.

\section{g. Nilai Cinta Damai}

Nilai cinta damai tersebut dapat dilihat dari sikap, perkataan, dan tindakan yang menyebabkan orang lain merasa senang dan aman atas kehadiran kita.

"Siap-siap, turunkan karungnya dulu"..

"Tangan didengkul semua"..

"1..2..3.."

(hiruk pikuk sorak gembira melihat lomba tersebut hingga ada yang sampai terjatuh pemainnya)

"Dudung.. Dudung (tertawa)"

(dan akhirnya dudung menang)

"Alhamdulillah. Allahhuakbar menang (ekspresi bahagia)". 


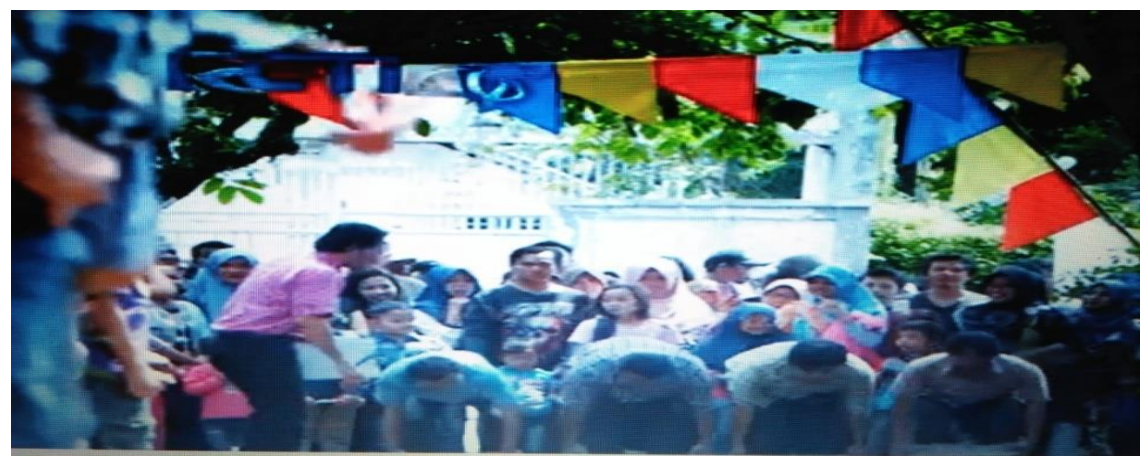

Gambar 7. Tokoh Akum dan Warga Ciraos dalam Sinetron Dunia Terbalik Episode 400

Nilai cinta damai pada nilai pendidikan karakter dalam sinetron Dunia Terbalik juga digambarkan pada perayaan acara 17 Agustus di desa Ciraos, disana tampak kebahagiaan mereka tanpa ada batasan satu sama lain. Yang mereka pegang adalah, mereka satu dan sama-sama warga Indonesia yang bahagia dan bangga bisa dapat merdeka. Warga Ciraos sama-sama mengadakan acara untuk perayaan acara 17 Agustus yaitu salah satunya lomba balap karung.

\section{h. Nilai Peduli Sosial}

Nilai peduli sosial yang dimaksud adalah sikap dan tindakan yang selalu ingin memberi bantuan pada orang lain dan masyarakat yang membutuhkannya.

"Assalamualaikum Kang.."

"Waalaikumsalam.."

"Maaf Kang, numpang tanya.."

"lya, mangga.."

"Akang tau rumahnya wak Suha?.."

"Nyari wak Suha atau nyari rumahnya wak Suha ?.."

"Nyari wak Suha Kang.."

"Oh, itu Cek. Icek nanti dipertigaan belok kanan. Nah wak Suha ada dirumah Aceng.."

"Rumahnya Aceng dimana ya Kang?.."

"Rumahnya Aceng didepan rumahnya Kang Dadang.."

"Dianter saja ya Cee.."

"Gak usah Kang.."

"Gampang kok Ce, pokoknya rumahnya itu didepannya ada pohon.." 


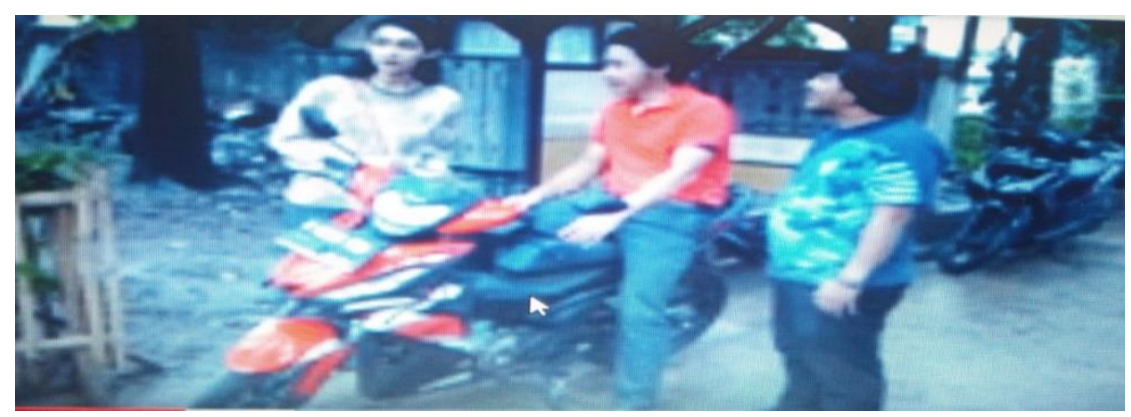

Gambar 8. Tokoh Akum, Idoy dan Lilis dalam Sinetron Dunia Terbalik Episode 404

Nilai peduli sosial pada adegan ini digambarkan oleh tokoh Akum dan Idoy yang dengan senang hati membantu orang lain yang bertanya kepada mereka. Dialog tersebut dilihat dengan tokoh Lilis yang menanyakan rumahnya Wak Suha kepada Akum dan Idoy, dan tokoh Akum ini juga menawarkan untuk mengantarkan perempuan (Lilis) yang sedang mencari Wak Suha. Tokoh Akum dan Idoy ini menggambarkan nilai yang baik yaitu nilai sosial yang menolong orang yang sedang mencari alamat walaupun mereka tidak mengenali orang tersebut, tetapi mereka tetap menolong tanpa mengharapkan imbalan dari perbuatan yang mereka lakukan.

\section{i. Nilai Tanggungjawab}

Nilai tanggung jawab tersebut merupakan sikap dan prilaku seseorang untuk melaksanakan tugas yang telah diberikan.

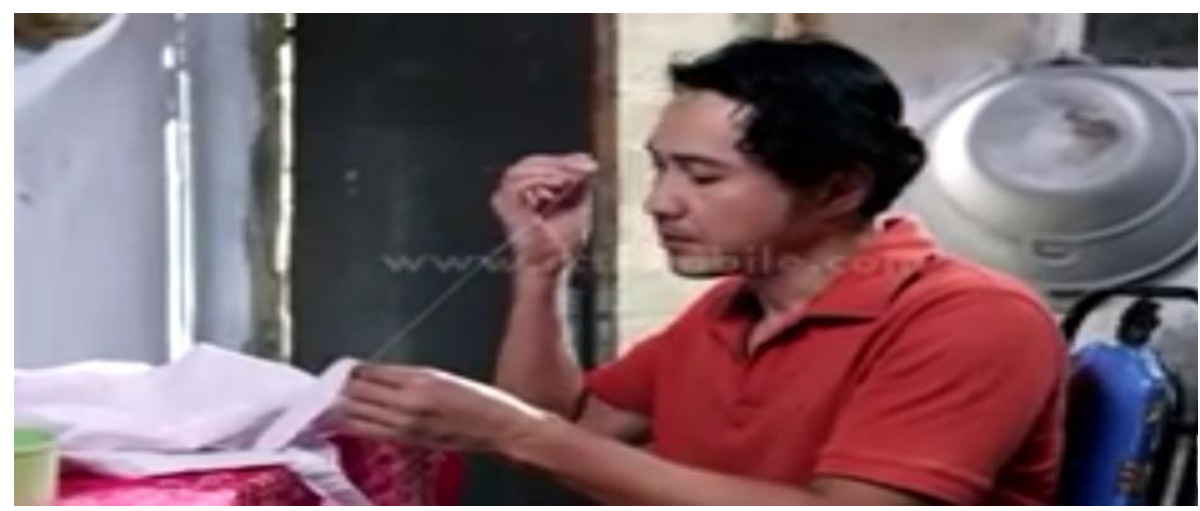

Gambar 9. Tokoh Akum dalam Sinetron Dunia Terbalik Episode 404

Tokoh Akum dalam sinetron Dunia Terbalik ini memiliki peran penting dalam setiap adegannya. Karena ia memiliki pribadi yang baik, yang dapat dijadikan panutan dan contoh yang baik oleh warga Ciraos dan untuk masyarakat yang menontonnya. Karena tokoh Akum ini, bisa melalukan amanah dan tanggung jawab yang telah diberikan istrinya selama istrinya berada diluar Negeri. Terlihat pada adegan ini, tokoh Akum dapat mengerjakan yang seharusnya dikerjakan oleh seorang perempuan atau seorang istri. Yaitu menjahit pakaian anaknya, tokoh akum ini menggambarkan pribadi yang baik karena bisa melakukan tanggung jawabnya dengan baik dan dapat dijadikan 
panutan yang baik. Selain itu, tokoh Akum ini adalah gambaran seorang suami serta ayah yang baik karena begitu sabar dalam menghadapi masalah apapun.

Hasil penelitian yang terdapat dalam nilai kejujuran, kesabaran, kerja keras, cinta tanah air, kekeluargaan, cinta damai, peduli sosial, dan tanggung jawab dapat disumbangkan pada tingkat Sekolah Menengah Pertama (SMP) dan dapat dijadikan sebagai media pembelajaran sastra Indonesia di kelas VIII semester 2 yang terdapat materi pokok tentang teks drama dengan Kompetensi Inti dan Kompetensi Dasar (KD) sebagai berikut:

Kompetensi Inti : 2. Menghargai dan menghayati prilaku jujur, disiplin, tanggung jawab, peduli (toleransi, gotong royong), santun, percaya diri, dalam berinteraksi secara efektif dengan lingkungan sosial dan alam dalam jangkauan pergaulan dan keberadaannya

Kompetensi Dasar $\quad$ : 2.1 Memiliki prilaku jujur dalam menceritakan sudut pandang moral yang eksplisit

2.2 Memiliki prilaku peduli, cinta tanah air, dan semangat kebangsaan atas karya budaya yang penuh makna

2.3 Memiliki prilaku demokratis, kreatif, dansantun dalam berdebat tentang kasus atau sudut pandang

2.4 Memiliki prilaku jujur dan percaya diri dalam mengungkapkan kembali tujuan dan metode serta hasil kegiatan

2.5 Memiliki prilaku jujur dan percaya diri dalam pengungkapan kembali peristiwa hidup diri sendiri dan orang lain

Hasil penelitian ini juga dapat di terapkan pada Sekolah Menengah Atas (SMA) dengan Kompetensi Inti dan Kompetensi Dasar (KD) SMA Kelas XI Semester 2 dengan materi drama:

Kompetensi Inti : $\quad 2$. Menghayati dan mengamalkan prilaku jujur, disiplin, tanggung jawab, peduli (gotong royong, kerjasama, toleran, damai), santun, responsif dan pro-aktif dan menunjukan sikap sebagai bagian dari solusi atas berbagai permasalahan dalam berinteraksi secara efektif dengan lingkungan sosial dan alam serta dalam

Kompetensi Dasar : 2.1 Menunjukkan prilaku tanggung jawab, responsif dan imajinatif dalam menggunakan bahasa Indonesia untukberekspresi

2.2 Menunjukkan prilaku tanggung jawab, peduli, dan proaktif dalam menggunakan bahasa Indonesia untuk memahami dan menyampaikan permasalahan

2.3 Menunjukkan prilaku jujur, tanggung jawab, dan disiplin dalam menggunakan bahasa Indonesia untuk bercerita ulang

2.4 Menunjukkan prilaku jujur, disiplin, peduli, dan santun dalam menggunakan bahasa Indonesia untuk menyampaikan paparan

2.5Menunjukkan prilaku jujur, peduli, santun, dan tanggung jawab dalam penggunaan bahasa Indonesia untuk menyampaikan penjelasan

Setelah kita melihat dan menemukan ke-9 nilai pendidikan karakter tersebut, maka peneliti dapat menyimpulan bahwa yang lebih menonjol nilai pendidikan karakter dalam sinetron Dunia Terbalik ini adalah yang pertama nilai religius yang sering muncul dan diperlihatkan dalam sinetron ini pada saat mereka mengingatkan dan mengajak satu sama lain dalam melakukan ajaran agama yang mereka anut. Nilai pendidikan karakter 
yang kedua yang sering menonjol adalah nilai kerja keras yang menjadikan mereka selalu berusaha apapun yang sedang terjadi. Nilai pendidikan karakter yang ketiga yaitu nilai peduli sosial yang juga menonjol dalam sinetron ini karena para warga masyarakat dalam sinetron ini sangat peduli satu sama lain dan suka senang menolong. Nilai pendidikan yang juga sering muncul dan menonjol yaitu nilai tanggung jawab yang diperankan para tokoh-tokoh dalam sinetron ini karena mereka tetap melaksanakan tugas dan tanggung jawab yang telah diamanahkan pada mereka.

Sedangkan yang ditemukan pada penelitian Rochmawati (2016:105-107), menyatakan bahwa dalam penelitian dengan judul Nilai-nilai Pendidikan Karakter dalam Film The Miracle Worker ada beberapa nilai pendidikan yang terdapat dalam Film tersebut diantaranya adalah: (1) Keyakinan (2) Kerja Keras (3) Ketulusan (4) Sabar dan (5) Menghargai. Hasil penelitian yang telah didapat dalam Film The Miracle Worker akan diimplikasikan kedalam pembentukan moral pada pembelajaran PAI yaitu Self Confidence, Self Spritualization, dan Self Actualization. Perbedaan penelitian ini dengan peneliti adalah media penelitian yang digunakan yaitu Sinetron Dunia Terbalik dan hasil penelitian yang didapat pada sinetron Dunia Terbalik ini yaitu nilai religius, kejujuran, kesabaran, kerja keras, cinta tanah air, kekeluargaan, cinta damai, peduli sosial, dan tanggung jawab. Dan sumbangan yang dilakukan oleh peneliti hanya memberikan hasil penelitian ini sebagai materi pembelajaran sastra Indonesia di sekolah.

Sejalan dengan penelitian Wijayanti (2013), menyatakan bahwa dalam penelitian yang dilakukan dengan judul Nilai-nilai Pendidikan Karakter dalam Film Rumah Tanpa Jendela Karya Aditya Gumay dan Relevansinya dengan Pendidikan Anak Usia MI menemukan beberapa nilai pendidikan karakter yang terdapat dalam Film Rumah Tanpa Jendela yaitu: nilai pendidikan karakter jujur, religius, kerja keras, mandiri, bersahabat atau komunikatif, peduli sosial, dan tanggung jawab yang akan di relevansinya dengan pendidikan anak usia MI. Hasil penelitian yang dapat dilihat dengan penelitian yang dilakukan oleh peneliti dalam sinetron Dunia Terbalik ini yaitu nilai-nilai pendidikan karakter yang terdapat dalam sebuah penelitian yang dilakukan hampir sama, tetapi yang membedakannnya hanya pada hasil penelitian yang dilakukan peneliti untuk menjadikan materi pembelajaran sastra Indonesia di sekolah.

Penelitian yang dilakukan Mutholangah (2015), menyatakan bahwa dalam penelitian dengan judul Nilai-nilai Pendidikan Karakter dalam Serial Animasi Adit dan Sopo Jarwo mendapatkan beberapa nilai-nilai pendidikan karakter yaitu yang pertama yaitu hubungannya dengan Tuhan YME yaitu ibadah berupa sholat dan berdo'a sebagai implementasi karakter imam, islam, insan, taqwa, ikhlas, tawakal, syukur dan sabar. Kedua nilai pendidikan karakter hubungannya dengan diri sendiri yaitu berfikir logis, kritis, kreatif dan inovatif, kerja keras, bertanggung jawab dan cinta ilmu. Ketiga nilai pendidikan karakter hubungannya dengan sesama manusia yaitu sadar akan hak dan kewajiban diri sendiri dan orang lain serta santu. Nilai-nilai pendidikan karakter dalam penelitian yang dilakukan pada serial animasi Adit dan Sopo Jarwo ini juga relevan dengan materi PAI di SD. Perbedaan dengan penelitian yang dilakukan peneliti dalam sinetron Dunia Terbalik yaitu pada media yang digunakan peneliti Sinetron Dunia Terbalik sedangkan penelitian yang dilakukan Mutholangah serial Animasi Adit dan Sopo Jarwo dan hasil nilai-nilai pendidikan karakter yang diperoleh dalam penelitian yang ditemukan juga sangat berbeda.

Linguista Vol. 2, No. 1, Juni 2018: $47-60$ 
Dalam penelitian Jayanto (2014), menyatakan bahwa dalam penelitian dengan judul Pengaruh Sinetron Tukang Bubur Naik Haji terhadap Pendidikan Akhlak Remaja (Studi Kasus di Dukuh Pengkol Kaligawe Pedan Klaten) mendapatkan hasil penelitian berupa pengaruh sinetron Tukang Bubur Naik Haji berupa: nilai pendidikan akhlak kepada Allah, nilai pendidikan akhlak terhadap manusia, nilai pendidikan akhlak terhadap alam, pengaruh Sinetron Tukang Bubur Naik Haji terhadap remaja meliputi pengaruh bersifat kognisi, afeksi, dan psiko-motorik. Perbedaan yang terdapat dalam penelitian yang dilakukan dalam peneliti yaitu pada media yang digunakan peneliti Sinetron Dunia Terbalik sedangkan penelitian Jayanto yaitu sinetron Tukang Bubur Naik Haji. Hasil yang diperoleh sangat berbeda dilihat dari nilai-nilai pendidikan karakter yang terdapat dalam masing-masing sinetron tersebut.

Maka Pembelajaran sastra Indonesia juga memperkenalkan nilai-nilai yang terkandung dalam karya sastra seperti yang terdapat dalam sinetron Dunia Terbalik ini dan mengajak siswa untuk ikut menghayati pengalaman-pengalaman yang disajikan dalam karya sastra. Sejalan dengan pendapat Abidin (2012:212), berpendapat bahwa pembelajaran sastra atau pembelajaran apresiasi sastra adalah serangkaian aktivitas yang dilakukan siswa untuk menemukan makna dan pengetahuan yang terkandung dalam karya sastra di bawah bimbingan, arahan, dan motivasi guru melalui kegiatan mengenalkan karya sastra tersebut secara langsung yang telah didukung dengan media yang ada.

Kaitan nilai karakter dengan sastra khususnya dalam sinetron Dunia Terbalik dan sumbangannya dalam pembelajaran sastra Indonesia ini sangat saling berkaitan. Tampak pada nilai-nilai karakter yang disampaikan dalam sinetron Dunia Terbalik. Nilai karakter yang terdapat dalam sinetron tersebut bisa dikembangkan untuk pembentukan karakter bangsa, seperti halnya yang sering digunakan dalam Kompetensi Inti dan Kompetensi Dasar (KD) yang ada dalam materi pembelajaran. Setiap tokoh dalam sinetron Dunia Terbalik menyampaikan nilai-nilai karakter tersendiri. Guru sebagai pendidik juga mampu menyampaikan nilai-nilai karakter tersebut agar lebih mudah dicerna oleh siswa. Sejalan dengan pendapat Dewi (2014), bawha karya sastra mampu menggambarkan kehidupan masyarakat pada zamannya. Cerita yang disajikan dalam karya sastra seperti Sinetron tidak hanya mengandung realita dan nilai pendidikan karakter. Sinetron juga bisa menggambarkan sebuah perjuangan atau nilai positif lainnya.

\section{Kesimpulan}

Nilai-nilai pendidikan karakter yang telah ditemukan dalam sinetron Dunia Terbalik ini yaitu nilai religius, kejujuran, kesabaran, kerja keras, cinta tanah air, kekeluargaan, cinta damai, peduli sosial, dan tanggung jawab diharapkan dapat diterapkan dalam pembelajaran Sastra Indonesia. Jika seorang anak dapat mengikuti proses belajar, maka akan membuat diri meraka jauh lebih baik dalam bertindak. Memiliki pola pikir yang berbeda dari sebelumnya, dan dapat mengambil tindakan dalam kondisi yang tenang. Proses pembelajaran sastra bertujuan untuk mengubah pola pikir dan tingkah laku mereka untuk jauh lebih baik dengan bantuan media sinetron Dunia Terbalik melalui nilai-nilai pendidikan yang terdapat dalam sinetron tersebut. Nilai-nilai 
pendidikan karakter tersebut dapat diterapkan dari tingkat Sekolah Menengah Pertama (SMP), Sekolah Menengah Atas (SMA), dan seterusnya. Dengan salah satu materi yang terdapat dalam Kompetensi Inti dan Kompetensi Dasar (KD) yaitu Drama, maka hasil penelitian sinetron Dunia Terbalik dapat dijadikan meteri pembelajaran Sastra Indonesia. Dengan tujuan, agar siswa disekolah dapat ditanamkan nilai pendidikan yang baik dan dapat diterapkan dalam kehidupan disekolah dan bermasyarakat. Berangkat dari kenyataan yang ada, banyak didalam diri siswa yang mulai pudarnya nilai pendidikan karakter yang baik. Oleh sebab itu, diharapkan hasil penelitian ini bisa dijadikan materi pembelajaran dalam Sastra Indonesia.

\section{Daftar Pustaka}

Abidin, Y. (2012). Pembelajaran Bahasa Berbasis Pendidikan Karakter. Bandung: PT. Refika Aditama.

Jayanto, N. (2014). Pengaruh Sinetron Tukang Bubur Naik Haji terhadap Pendidikan Akhlak Remaja (Studi Kasus di Dukuh Pengkol Kaligawe Pedan Klaten, Jurnal Harmoni Sosial, 1 (1).

Mutholangah, S. (2015). Nilai-Nilai Pendidikan Karakter dalam Serial Animasi Adit dan Sopo Jarwo, Akademika Jurnal Kebudayaan, 1 (1).

Mulyasa, E. (2014). Manejemen Pendidikan Karakter. Jakarta: Bumi Aksara.

Rochmawati, W. P. (2016). Analisis nilai-nilai pendidikan karakter dalam film "The Miracle Worker" (Doctoral dissertation, Universitas Islam Negeri Maulana Malik Ibrahim).

Wibowo, A. (2012). Pendidikan Karakter: Membangun Karakter Bangsa Berperadaban. Yogyakarta: Pustaka Pelajar.

Wijayanti, M. N. (2013). Nilai-nilai Pendidikan Karakter dalam Film Rumah Tanpa Jendela Karya Aditya Gumay dan Relevansinya dengan Pendidikan Anak Usia MI,

(Online), (file:///D:/JURNAL/BAB\%201\%252C\%20IV\%252C\%20DAFTAR\%20PUSTAKA. pdf. Diunduh 10 September 2017). 